\title{
Burkholderia rhizoxinica sp. nov. and Burkholderia endofungorum sp. nov., bacterial endosymbionts of the plant-pathogenic fungus Rhizopus microsporus
}

Correspondence

Christian Hertweck

Christian.Hertweck@hki-jena.de

\author{
Laila P. Partida-Martinez, ${ }^{1}$ Ingrid Groth, ${ }^{1}$ Imke Schmitt, ${ }^{1}$ Walter Richter, ${ }^{2}$ \\ Martin Roth ${ }^{1}$ and Christian Hertweck ${ }^{1,3}$
}

\author{
${ }^{1}$ Leibniz Institute for Natural Product Research and Infection Biology, HKI, Jena, Germany \\ ${ }^{2}$ Centre for Electron Microscopy of the Medical Faculty at the Friedrich Schiller University, Jena, \\ Germany \\ ${ }^{3}$ Friedrich Schiller University, Jena, Germany
}

\begin{abstract}
Several strains of the fungus Rhizopus microsporus harbour endosymbiotic bacteria for the production of the causal agent of rice seedling blight, rhizoxin, and the toxic cyclopeptide rhizonin. $R$. microsporus and isolated endobacteria were selected for freeze-fracture electron microscopy, which allowed visualization of bacterial cells within the fungal cytosol by their two parallel-running envelope membranes and by the fine structure of the lipopolysaccharide layer of the outer membrane. Two representatives of bacterial endosymbionts were chosen for phylogenetic analyses on the basis of full $16 \mathrm{~S}$ rRNA gene sequences, which revealed that the novel fungal endosymbionts formed a monophyletic group within the genus Burkholderia. Inter-sequence similarities ranged from 98.94 to $100 \%$, and sequence similarities to members of the Burkholderia pseudomallei group, the closest neighbours, were $96.74-97.38 \%$. In addition, the bacterial strains were distinguished from their phylogenetic neighbours by their fatty acid profiles and other biochemical characteristics. The phylogenetic studies based on 16S rRNA gene sequence data, together with conclusive DNA-DNA reassociation experiments, strongly support the proposal that these strains represent two novel species within the genus Burkholderia, for which the names Burkholderia rhizoxinica sp. nov. (type strain, HKI $454^{\top}=\mathrm{DSM} 19002^{\top}=\mathrm{CIP}$ $109453^{\top}$ ) and Burkholderia endofungorum sp. nov. (type strain, HKI $456^{\top}=$ DSM $19003^{\top}=$ CIP $109454^{\top}$ ) are proposed.
\end{abstract}

The genus Burkholderia comprises a group of metabolically versatile bacteria (Yabuuchi et al., 1992) that occupy remarkably diverse ecological niches (Coenye \& Vandamme, 2003), such as terrestrial and aquatic environments (Zhang et al., 2000; Bramer et al., 2001; Goris et al., 2004; Yang et al., 2006), the plant rhizosphere (Viallard et al., 1998; Caballero-Mellado et al., 2004), animals and humans (Coenye \& Vandamme, 2003). Several members of the genus Burkholderia live in symbiosis, e.g. with vascular plants (Van Oevelen et al., 2002, 2004), arbuscular mycorrhizal (AM) fungi (Bianciotto et al., 2003) and basidiomycetes (Lim et al., 2003). Recently, we discovered a unique symbiosis between bacteria belonging to the genus Burkholderia and the saprotrophic fungus Rhizopus

Abbreviations: AM, arbuscular mycorrhizal; MP, maximum-parsimony; $\mathrm{NJ}$, neighbour-joining; PP, posterior probability.

The GenBank/EMBL/DDBJ accession numbers for the 16S rRNA gene sequences of strains $\mathrm{HKI} 454^{\top}$ and $\mathrm{HKI} 456^{\top}$ are AJ938142 and AM420302, respectively. microsporus. We noted that these bacteria live within the fungal cells and that they are the true producers of rhizoxin, the causative agent of rice seedling blight (PartidaMartinez \& Hertweck, 2005, 2007; Scherlach et al., 2006). In a subsequent study, we found that the endofungal bacteria are also responsible for the production of the 'mycotoxin' rhizonin (Partida-Martinez et al., 2007a). This intriguing phytopathogenic alliance against rice seedlings represents an unprecedented example in which a fungus hosts a bacterial population for the production of a virulence factor (Partida-Martinez \& Hertweck, 2005). Since the first observation of 'bacterium-like organelles' in the cytoplasm of AM fungi in the early 1980s, only very few reports about the occurrence of endofungal bacteria have been published (Bonfante, 2003; Bianciotto et al., 2003; Boer et al., 2005; Lumini et al., 2006). However, in all cases, the symbionts resisted cultivation in cell-free medium and could only be investigated by using molecular methods (Van Oevelen et al., 2002). In contrast, bacterial endosymbionts of $R$. microsporus strains could be isolated, 
grown in pure culture and reintroduced into a cured fungal host strain (Partida-Martinez \& Hertweck, 2005; Scherlach et al., 2006; Partida-Martinez et al., 2007a, b).

In the present study, we provide further support for the occurrence of endofungal bacteria in fungal strains of the genus Rhizopus by freeze-fracture electron microscopy, and determine the taxonomic position of two bacterial endosymbionts by $16 \mathrm{~S}$ rRNA gene-based phylogenetic reconstruction, DNA-DNA hybridization and further biochemical data.

\section{Bacterial endosymbionts of $\boldsymbol{R}$. microsporus}

Bacterial endosymbionts of $R$. microsporus ATCC 62417 were initially visualized in the cytosol by staining fungal preparations from a growing fungal culture with a mixture of dyes (SYTO 9 and propidium iodide). The samples were treated with a fluorescence enhancer and analysed by using a confocal laser microscope, showing that mycelium of $R$. microsporus harboured a high number of living endobacteria (Partida-Martinez \& Hertweck, 2005). Endosymbionts of $R$. microsporus CBS 112285, a toxinogenic strain isolated from ground nuts, were visualized by transmission electron microscopy (Partida-Martinez et al., 2007a). We succeeded in isolating bacterial symbionts from mycelium of both fungal strains (Table 1). The mycelium was broken by mechanical stress (pipetting) and sedimented by centrifugation for $30 \mathrm{~min}$ at $13200 \mathrm{r}$.p.m. $(16100 \mathrm{~g})$. A loop of the supernatant was plated on nutrient agar I (Serva) plates and incubated at $30{ }^{\circ} \mathrm{C}$ until bacterial growth was observed. Bacterial colonies were then cultured in Bacto tryptic soy broth (TSB; Difco) and preserved at $-80{ }^{\circ} \mathrm{C}$ as a $1: 1$ mixture of culture broth and glycerol.

Fungus $R$. microsporus van Tieghem ATCC 62417 and its recovered isolated endobacteria were selected for freezefracture electron microscopy. Samples were cultivated as described above and washed twice with saline solution or fresh medium. For cryoprotection, glycerol was added to all cell suspensions to a final concentration of $20 \%(\mathrm{v} / \mathrm{v})$. Aliquots of these suspensions were enclosed between $0.1 \mathrm{~mm}$ thick copper profiles (BAL-TEC) as used for the sandwich double-replica technique. The sandwiches were frozen rapidly by plunging them into a $1: 1$ mixture of

Table 1. Fungal strains and their symbionts

\begin{tabular}{|llcl|}
\hline Taxon & Collection no. & Origin & $\begin{array}{c}\text { Bacterial } \\
\text { endosymbiont }\end{array}$ \\
\hline $\begin{array}{l}\text { Rhizopus } \\
\text { microsporus }\end{array}$ & ATCC 62417 & $\begin{array}{c}\text { Rice seedlings, } \\
\text { van Tieghem }\end{array}$ & $\begin{array}{c}\text { Burkholderia } \\
\text { rhizoxinica }\end{array}$ \\
var. chinensis & & Japan & HKI 454 ${ }^{\mathrm{T}}$ \\
Rhizopus & CBS 112285 & Ground nuts, & Burkholderia \\
microsporus & & Mozambique & $\begin{array}{c}\text { endofungorum } \\
\text { Tieghem }\end{array}$ \\
& & & HKI 456 \\
\hline
\end{tabular}

liquid ethane: propane cooled by liquid nitrogen. Freezefracturing was performed in a BAF400T (BAL-TEC) freeze-fracture device at $-150{ }^{\circ} \mathrm{C}$ using a double replica stage. For replication, in a first step, $2 \mathrm{~nm}$ platinum was evaporated under an angle of $35^{\circ}$ and, in a second step, about $30 \mathrm{~nm}$ carbon under $90^{\circ}$. Evaporation was done by electron-gun evaporators and controlled by thin-layer quartz crystal monitoring. Replicas were floated onto the surface of a small amount of water, cleaned in sodium hypochlorite (bacteria) and hot sulphuric acid [70 \% (v/v), hyphae], washed three times with double-distilled water and mounted to mesh 400 electron microscopical copper grids. Replicas were investigated in an EM 900 electron microscope (Zeiss). Bacterial cells can be identified clearly within the fungal cytosol by their two parallel-running envelope membranes, in particular by the fine structure of the lipopolysaccharide layer of the outer membrane (Fig. $1 b, d)$.

\section{Phylogenetic analysis}

To establish the taxonomic position of the bacterial symbionts, both metagenomic DNA from rhizoxin-producing fungal species and genomic DNA from the recovered endobacterial strains were isolated and amplified by using $16 \mathrm{~S}$ universal primers, as described previously (PartidaMartinez \& Hertweck, 2005). Database searches based on their full-length 16S rRNA gene sequences (1525 and $1527 \mathrm{bp}$ ) revealed that the isolated endosymbiotic bacteria are related closely to organisms belonging to the genus Burkholderia, and that each fungus contains only one bacterial strain.

For phylogenetic analyses, 16S rRNA gene sequences of 36 type strains of species belonging to the genus Burkholderia were retrieved from GenBank. We also included three representatives of the closely related genus Pandoraea and four members of the genus Ralstonia, which were used as outgroups. Sequences were aligned by using CLUSTAL W (Thompson et al., 1997). The manually optimized alignment included 1422 sites, 264 of which were variable and 213 of which were parsimony-informative. Phylogenetic analyses were carried out in a Bayesian, maximumparsimony and distance-matrix framework (Schmitt \& Lumbsch, 2004). Bayesian tree sampling was performed by using the MRBAYES 3.1.2 program (Huelsenbeck \& Ronquist, 2001; Huelsenbeck et al., 2001). We employed the general time-reversible model of nucleotide evolution, including estimation of invariant sites and assuming a discrete gamma distribution $(\mathrm{GTR}+\mathrm{I}+\Gamma)$. Two analyses, including $5 \times 10^{6}$ generations each, were run in parallel. Eight chains were run simultaneously. Trees were sampled every 1000 generations for a total of $2 \times 5000$ trees. The first $1 \times 10^{6}$ generations (i.e. the first 1000 trees of each analysis) were deleted as the 'burn-in' of the chain. We plotted the log-likelihood scores of sample points against generation time by using TRACER 1.0 (http://evolve.zoo.ox.ac.uk/ software.html?id=tracer) to ensure that stationarity was 

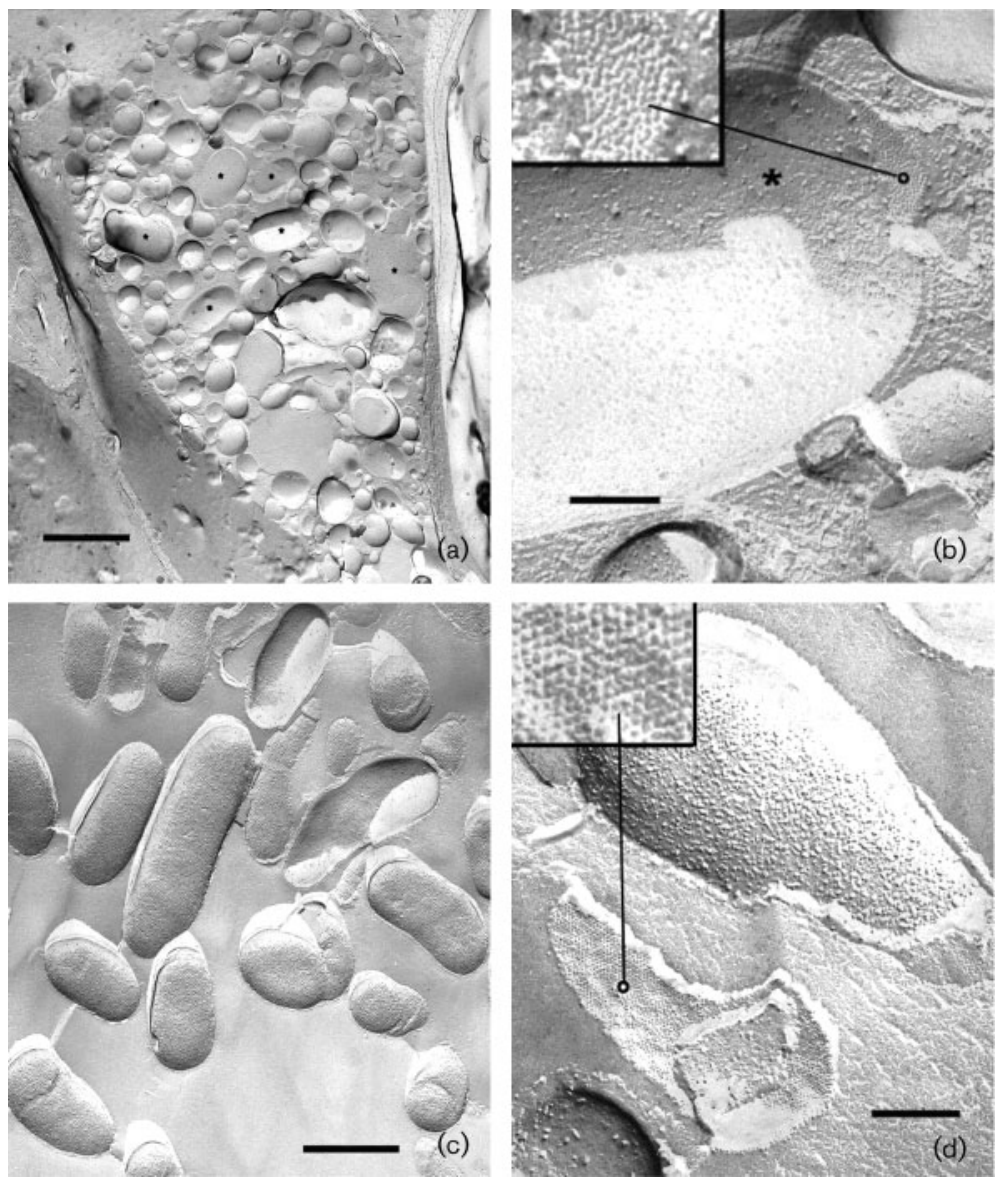

Fig. 1. Freeze-fracture electron images. (a) Fungus $R$. microsporus van Tieghem ATCC 62417 with intrahyphal bacteria (small stars). (b) Enlarged view of (a), showing the two parallel-running envelopes of a bacterium, the cytoplasmic membrane (star) and the lipopolysaccharide (LPS) layer of the outer membrane (o), with its special fine structure (inset) typical of Gram-negative bacteria. (c) Bacterial cells isolated from $R$. microsporus van Tieghem ATCC 62417 and cultivated in pure culture. (d) Cultivated bacteria at high magnification, showing the LPS layer of the outer membrane (o, inset) in comparison to (b). Micrographs were mounted with direction of platinum evaporation from bottom to top. Bars, $2 \mu \mathrm{m}$ (a); $1 \mu \mathrm{m}$ (c); $200 \mathrm{~nm}$ (b, d). achieved after the first $1 \times 10^{6}$ generations by checking whether the log-likelihood values of the sample points reached a stable equilibrium value (Huelsenbeck \& Ronquist, 2001). Of the remaining $2 \times 4000$ trees, a majority-rule consensus tree including branch lengths was calculated by using the 'sumt' option in MRBAYES. Branch support is calculated as posterior probability (PP), indicating the number of times a branch is present in the tree topology in relation to its presence in the total number of sampled trees. PPs $\geqslant 95 \%$ are regarded as significant. In addition, maximum-parsimony (MP) and neighbour-joining $(\mathrm{NJ})$ analyses were performed by using the program PAUP (Swofford, 2003). For the MP analysis, 200 randomaddition replicates were run. We obtained 70 mostparsimonious trees, of which we calculated the strict consensus (897 steps, consensus index $=0.41$, reliability index $=0.72$ ). Neighbour-joining trees were constructed by fitting the LogDet model to the data (minimum evolution), which corrects for nucleotide-substitution inequalities along branches. Branch support for MP and NJ trees was obtained by performing 2000 simple-addition bootstrap replicates. Phylogenetic trees were visualized by using the program TreeView (Page, 1996). Tree topologies obtained with different reconstruction methods were very similar and showed no supported conflicts. Therefore, only the Bayesian phylogenetic estimate is presented (Fig. 2).
Phylogenetic analyses show that the novel fungal endosymbionts form a monophyletic group within the highly supported genus Burkholderia (Fig. 2). Inter-sequence similarity is $99.22 \%$. As most phylogenetic relationships within the genus Burkholderia are not supported, it is difficult to determine the closest relative of the novel endosymbiont species by using the current dataset. BLAST searches against GenBank indicate that Burkholderia mallei, Burkholderia pseudomallei, Burkholderia vietnamiensis and Burkholderia thailandensis (Brett et al., 1998) are probably most similar to the novel species in 16S rRNA gene sequence. Sequence similarities to these sequences are 96.74-97.38\%. Members of the Burkholderia cepacia complex, e.g. B. cepacia, Burkholderia multivorans, Burkholderia pyrrocinia, Burkholderia stabilis and B. vietnamensis (Coenye et al., 2001a, b, c, d), and Burkholderia caryophylli, a parasitic endophyte infecting vascular plants (Burkholder, 1942), also appear to be related closely to the novel species.

Several members of the genus Burkholderia live in symbiosis or are associated with other organisms, e.g. with plants (Viallard et al., 1998; Van Oevelen et al., 2002, 2004; Caballero-Mellado et al., 2004; Reis et al., 2004; Sessitsch et al., 2005), AM fungi (Bianciotto et al., 2003) and basidiomycota (Coenye et al., 2001b; Lim et al., 2003). The phylogenetic placement of the novel bacterial species, 


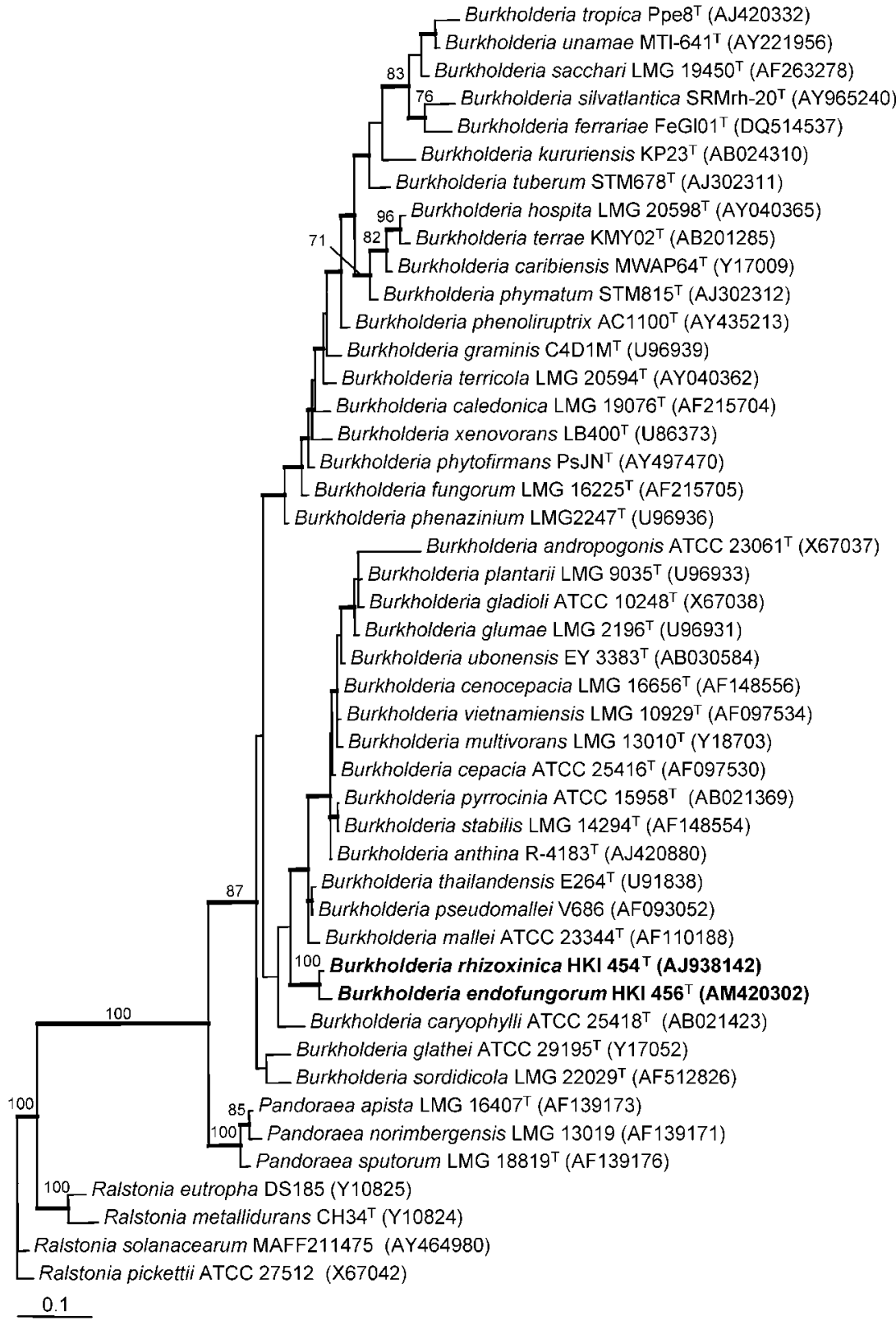

Fig. 2. Phylogenetic position of the genus Burkholderia and related genera based on $16 S$ rRNA gene sequences. The newly described endofungal species are indicated in bold. GenBank accession numbers are given in parentheses. This is a $50 \%$ majority-rule consensus tree based on 8000 trees of a Bayesian Markov chain Monte Carlo analysis. Bold branches indicate posterior probabilities $>94 \%$. Numbers above branches are maximum-parsimony bootstrap-support values $>70 \%$, based on 2000 pseudoreplicates. Bar, 0.1 genetic distance. which form endosymbioses with zygomycota, gives further evidence of the broad ecological amplitude of the genus Burkholderia.

\section{DNA-DNA relatedness}

The results obtained from phylogenetic studies were supported strongly by DNA-DNA hybridization experiments performed by the Deutsche Sammlung von Mikroorganismen und Zellkulturen (DSMZ), Braunschweig, Germany. Type strains of Burkholderia rhizoxinica (HKI $454)$ and B. thailandensis exhibited a low DNA-DNA reassociation level (19.2\%). Analysis of the closely related strains HKI $454^{\mathrm{T}}$ and HKI $456^{\mathrm{T}}$ revealed a reassociation value of $43.2 \%$. Both values are well below $70 \%$. This result demonstrates that not only is HKI $454^{\mathrm{T}}$ sufficiently distant from related Burkholderia species to be recognized as an independent taxospecies, but also that HKI $454^{\mathrm{T}}$ and HKI $456^{\mathrm{T}}$ represent distinct species.

\section{Other taxonomic characteristics}

Morphological studies, determination of growth parameters and cellular fatty acid analyses of the bacterial isolates and the type strain of B. thailandensis, DSM $13276^{\mathrm{T}}$ (Brett et al., 1998), were performed in TSB or on Bacto tryptic soy agar (TSA; Difco), nutrient agar I and LuriaBertani (LB) agar at an incubation temperature of $30{ }^{\circ} \mathrm{C}$. Cell morphology and cell dimensions were examined by phase-contrast microscopy using a Zeiss Axioscope 2 
microscope equipped with image-analysing software (Axio Vision 2.05) and by freeze-fracture electron microscopy as described above.

Gram staining was performed according to Hucker's modification (Cowan \& Steel, 1965) with reagents produced by bioMérieux. Cytochrome $c$ oxidase activity was studied by monitoring the oxidation of $N, N, N^{\prime}, N^{\prime}$-tetramethylphenylenediamine dihydrochloride on DrySlide oxidase (Difco). Catalase activity was determined as described by Smibert \& Krieg (1994). For testing tolerance to $\mathrm{NaCl}$, the cultures were grown on TSA and in TSB at $30{ }^{\circ} \mathrm{C}$. Growth parameters of strains HKI $454^{\mathrm{T}}$ and HKI $456^{\mathrm{T}}$ were investigated with $300 \mathrm{ml}$ aerated submerged cultures using $500 \mathrm{ml}$ vessels of the multifermenter system Biostat Q (B. Braun Biotech International). Trypticase soy broth (BBL; $\left.30 \mathrm{~g} \mathrm{l}^{-1}\right)$ supplemented with glycerol $\left(10 \mathrm{~g} \mathrm{l}^{-1}\right)$ was used for cultivation. The $\mathrm{pH}$ value and dissolved oxygen tension were measured by respective sensors. $\mathrm{pH}$ of cultures was adjusted and controlled by the $\mathrm{pH}$-control system of the fermenter using $0.5 \mathrm{M} \mathrm{NaOH}$ and $0.5 \mathrm{M} \mathrm{HCl}$. For determining the $\mathrm{pH}$ range for growth, the $\mathrm{pH}$ value of the culture medium was first adjusted to the $\mathrm{pH}$ of the inoculum. After inoculation, the $\mathrm{pH}$ of the respective culture was adjusted within $4 \mathrm{~h}$ to the desired end value. In total, 10 different $\mathrm{pH}$ values ranging from 3.5 to 9.5 were tested. Viability of cells during the cultivation process was examined by plating samples on agar medium at different intervals. Growth was examined by measuring $\mathrm{OD}_{600}$. Concentration of glycerol was determined by HPLC. Oxygen requirement was studied by incubation of inoculated agar plates (nutrient agar I) in GENbag microaer and GENbag anaer incubation systems (bioMérieux). For analysis of cellular fatty acids, the strains were cultivated for $48 \mathrm{~h}$ at $30{ }^{\circ} \mathrm{C}$ in shake flasks containing TSB. Biomass was separated from the culture broth by centrifugation. Due to the poor growth of the strains under study, biomass had to be collected from several flasks inoculated with the same culture. Fatty acid profiles were determined by using the MIDI system (Agilent) according to the instructions of the manufacturer. For testing enzymic activities by using the API ZYM system (bioMérieux), the strains under investigation were cultivated for 24 or $48 \mathrm{~h}$ on TSA plates. To determine the utilization of various carbon sources, the commercial test systems API 20NE, API 50CH/BE (bioMérieux) and GN2 MicroPlates (Biolog) were used. Susceptibility to antibiotics was examined by placing antibiotic discs (Difco) on nutrient agar I plates seeded with the test strains grown for $24-48 \mathrm{~h}$ at $30{ }^{\circ} \mathrm{C}$ in submerged cultures.

Although the endosymbiotic bacteria could be cultivated in both liquid and solid media, many of the required tests to characterize them fully could not be carried out. Growth of all isolates was poor on agar plates and typically occurred as a very thin lawn. Single colonies, if they appeared, grew very slowly. Subcultivation was generally erratic and only successful when the agar plates were incubated under high humidity. On dry agar plates, no growth occurred. Due to the poor growth of the strains under investigation, biomass had to be collected from several flasks inoculated with the same culture. Despite the facts that different cultures of the isolates were used as inocula for the test systems API 20NE, API 50CH/BE (bioMérieux) and GN2 MicroPlates (Biolog) and that repeated tests were performed, in all cases a very high number of negative results was obtained. Only a few variable results indicated that the isolates were able to hydrolyse aesculin, gelatin and Tween 80 and to utilize glycerol, L-glutamic acid and succinamic acid. Confident results were obtained for the cellular fatty acid composition (Table 2), enzymic activity using the API ZYM system and susceptibility to some antibiotics (Table 3). All major results obtained are summarized in the species description.

In conclusion, we have demonstrated that $R$. microsporus is associated with bacterial endosymbionts that can be distinguished clearly from their phylogenetic neighbours by their fatty acid profiles and other biochemical characteristics. Apparently, the endosymbionts are highly adapted to their hosts. For this reason, growth of these bacteria is erratic in pure culture and does not allow a polyphasic taxonomic study. Nevertheless, our phylogenetic studies based on 16S rRNA gene sequence data, together with the phenotypic characteristics and DNA-DNA hybridization, strongly support the proposal that the strains represent two novel species within the genus Burkholderia, for which the names Burkholderia rhizoxinica sp. nov. and Burkholderia endofungorum sp. nov. are proposed.

\section{Description of Burkholderia rhizoxinica sp. nov.}

Burkholderia rhizoxinica (rhi.zo.xi' ni.ca. N.L. n. rhizoxinum rhizoxin; L. f. suff. -ica suffix used with various meanings; N.L. fem. adj. rhizoxinica referring to the ability of this organism to produce the antimitotic agent rhizoxin).

Irregularly cultured, Gram-negative, motile, short or coccoid rods that occur singly, in pairs or irregular clusters. Cell size varies from 1.2 to $2.0 \mu \mathrm{m}$ in length and from 0.6 to $1.2 \mu \mathrm{m}$ in width. Cells are positive for oxidase and catalase. Single colonies are tiny, circular, flat, glistening and of cream colour (about $1 \mathrm{~mm}$ in diameter). Growth is poor on agar plates and typically occurs as a very thin lawn. Production of diffusible pigments is not observed. $\mathrm{NaCl}$ is tolerated well up to a concentration of $2 \%(\mathrm{w} / \mathrm{v})$. Growth is negative or weak at a concentration of $3 \%(\mathrm{w} / \mathrm{v}) \mathrm{NaCl}$ and is inhibited completely at $5 \%(\mathrm{w} / \mathrm{v}) \mathrm{NaCl}$. The type strain is able to grow at temperatures between 16 and $45{ }^{\circ} \mathrm{C}$ and at a $\mathrm{pH}$ range of 5.0-7.4. Optimum $\mathrm{pH}$ is 6.0-6.5. Cells are not viable at $\mathrm{pH}$ values below 4.5 or above 7.5. In cultures without $\mathrm{pH}$ control, growth stops at $\mathrm{pH}$ 7.5. Glucose is not metabolized, but glycerol is utilized. Able to grow under aerobic and microaerophilic conditions, but not in an anaerobic atmosphere containing $\mathrm{CO}_{2}$.

Phylogenetic distinctiveness is supported by the fatty acid profile, which is characterized by major amounts of 
Table 2. Cellular fatty acid profiles of novel Burkholderia strains

Strains: 1 , B. thailandensis DSM $13276^{\mathrm{T}} ; 2$, B. rhizoxinica $\mathrm{HKI} 454^{\mathrm{T}} ; 3$, B. endofungorum HKI $456^{\mathrm{T}}$.

\begin{tabular}{|c|c|c|c|}
\hline Fatty acid & 1 & 2 & 3 \\
\hline \multicolumn{4}{|l|}{ Saturated } \\
\hline $10: 0$ & 0.05 & - & - \\
\hline $12: 0$ & 0.05 & 0.14 & 0.13 \\
\hline $14: 0$ & 3.71 & 3.29 & 3.94 \\
\hline $15: 0$ & 0.43 & 0.11 & 0.14 \\
\hline $16: 0$ & 28.14 & 14.86 & 17.48 \\
\hline $17: 0$ & 0.64 & 0.11 & 0.13 \\
\hline $18: 0$ & 0.92 & 1.62 & 1.35 \\
\hline $12: 03-\mathrm{OH}$ & - & - & - \\
\hline $15: 03-\mathrm{OH}$ & 0.08 & - & - \\
\hline $16: 02-\mathrm{OH}$ & 2.42 & 1.92 & 1.47 \\
\hline $16: 03-\mathrm{OH}$ & 5.10 & 4.75 & 4.95 \\
\hline $18: 02-\mathrm{OH}$ & - & - & 0.11 \\
\hline \multicolumn{4}{|l|}{ Unsaturated } \\
\hline $13: 1 \mathrm{AT} 12-13$ & - & - & - \\
\hline $14: 1 \omega 5 c$ & - & - & 0.09 \\
\hline $16: 1 \omega 5 c$ & 0.30 & 0.13 & 0.29 \\
\hline $18: 1 \omega 5 c$ & 0.49 & 0.21 & 0.23 \\
\hline $17: 1 \omega 7 c$ & - & - & - \\
\hline $18: 1 \omega 7 c$ & 0.91 & 37.27 & 21.94 \\
\hline $18: 3 \omega 6 c$ & - & - & - \\
\hline $20: 2 \omega 6,9 c$ & 0.35 & 0.29 & 0.36 \\
\hline $16: 12-\mathrm{OH}$ & 0.61 & 2.47 & 3.61 \\
\hline $18: 12-\mathrm{OH}$ & 1.63 & 2.77 & 2.51 \\
\hline \multicolumn{4}{|l|}{ Branched } \\
\hline$i-15: 0$ & - & - & - \\
\hline $\mathrm{i}-16: 0$ & - & 0.12 & 0.92 \\
\hline $\mathrm{i}-19: 0$ & 0.31 & 0.26 & 0.33 \\
\hline ai-11:0 & 0.04 & - & - \\
\hline ai-15:0 & - & - & - \\
\hline ai-19:0 & 0.24 & - & - \\
\hline \multicolumn{4}{|l|}{ 10-Methyl } \\
\hline $17: 0$ & - & - & - \\
\hline \multicolumn{4}{|l|}{ 11-Methyl } \\
\hline $18: 1 \omega 7 c$ & 0.44 & 0.37 & 0.39 \\
\hline \multicolumn{4}{|l|}{ Cyclo } \\
\hline $17: 0$ & 19.36 & 6.45 & 12.06 \\
\hline $19: 0 \omega 8 c$ & 28.46 & 11.09 & 16.42 \\
\hline \multicolumn{4}{|l|}{ Others } \\
\hline Feature $1^{\star}$ & - & - & - \\
\hline Feature $2^{*}$ & 4.61 & 3.08 & 2.61 \\
\hline Feature $3^{*}$ & 0.52 & 8.71 & 8.48 \\
\hline Unknown 14.502 & 0.17 & - & - \\
\hline Unknown 18.814 & - & - & - \\
\hline 16:0 $N$ alcohol & - & - & - \\
\hline ai $17: 1 \omega 9 c$ & - & - & 0.06 \\
\hline
\end{tabular}

*Unknown fatty acids; these compounds do not have a listed name in the Peak Library File of the MIDI system and therefore were not identified.

hexadecanoic acid (C16:0), cyclo-heptadecanoic acid (C17:0 cyclo), $\omega-7$-cis-octadecenoic acid $(\mathrm{C} 18: 1 \omega 7 c)$ and cyclo- $\omega$-8-nanodecanoic acid $(\mathrm{C} 19: 0 \omega 8 c)$. Positive
Table 3. Enzymic activity obtained by using the API ZYM system

Strains: 1 , B. thailandensis DSM $13276^{\mathrm{T}} ; 2$, B. rhizoxinica HKI $454^{\mathrm{T}} ; 3$, B. endofungorum HKI $456^{\mathrm{T}}$. Characteristics: - , no enzymic reaction; + , positive enzymic reaction; $\mathrm{w}$, weak enzymic reaction observed. Antibiotic susceptibility by novel endofungal bacteria (concentration per disc): - , no inhibition of growth; + , inhibition of growth; $(+)$, slight inhibition of growth; NT, not tested.

\begin{tabular}{|c|c|c|c|}
\hline Characteristic & 1 & 2 & 3 \\
\hline Phosphatase alkaline & + & - & - \\
\hline Esterase (C4) & + & + & + \\
\hline Esterase lipase (C8) & + & + & + \\
\hline Lipase (C14) & + & - & - \\
\hline Leucine arylamidase & + & + & + \\
\hline Valine arylamidase & + & - & + \\
\hline Cystine arylamidase & + & - & - \\
\hline Trypsin & - & - & - \\
\hline$\alpha$-Chymotrypsin & - & - & - \\
\hline Phosphatase acid & + & - & - \\
\hline Naphthol-AS-BI-phosphohydrolase & + & + & + \\
\hline$\alpha$-Galactosidase & - & - & - \\
\hline$\beta$-Galactosidase & - & - & - \\
\hline$\beta$-Glucuronidase & - & - & - \\
\hline$\alpha$-Glucosidase & - & - & - \\
\hline$\beta$-Glucosidase & - & - & - \\
\hline$N$-Acetyl- $\beta$-glucosamidase & + & - & - \\
\hline$\alpha$-Mannosidase & - & + & - \\
\hline$\alpha$-Fucosidase & - & - & - \\
\hline \multicolumn{4}{|l|}{ Antibiotic sensitivity } \\
\hline Ampicillin, $10 \mu \mathrm{g}$ & - & - & - \\
\hline Chloramphenicol, $30 \mu \mathrm{g}$ & + & + & + \\
\hline Ciprofloxacin, $5 \mu \mathrm{g}$ & + & + & + \\
\hline Imipenem, $10 \mu \mathrm{g}$ & + & + & + \\
\hline Kanamycin, $30 \mu \mathrm{g}$ & - & + & + \\
\hline Lincomycin, $2 \mu \mathrm{g}$ & - & - & - \\
\hline Meticillin, $5 \mu \mathrm{g}$ & - & - & - \\
\hline Nalidixic acid, $30 \mu \mathrm{g}$ & + & + & + \\
\hline Norfloxacin, $10 \mu \mathrm{g}$ & + & + & + \\
\hline Novobiocin, $5 \mu \mathrm{g}$ & + & - & - \\
\hline Ofloxacin, $10 \mu \mathrm{g}$ & + & NT & NT \\
\hline Oxytetracycline, $30 \mu \mathrm{g}$ & + & + & + \\
\hline Penicillin G, 10 IU & - & - & - \\
\hline Polymyxin B, $300 \mathrm{IU}$ & - & + & - \\
\hline Rifampicin, $30 \mu \mathrm{g}$ & + & NT & NT \\
\hline Rifampicin, $5 \mu \mathrm{g}$ & - & + & + \\
\hline Streptomycin, $10 \mu \mathrm{g}$ & - & + & + \\
\hline Sulfonamide, $200 \mu \mathrm{g}$ & - & - & - \\
\hline Tetracycline, $30 \mu \mathrm{g}$ & + & + & + \\
\hline Vancomycin, $30 \mu \mathrm{g}$ & - & - & - \\
\hline
\end{tabular}

reactions are obtained for esterase (C4), esterase lipase (C8), leucine arylamidase, L-mannosidase and naphtholAS-BI-phosphohydrolase. Alkaline phosphatase, cystine arylamidase, acid phosphatase and $N$-acetyl- $\beta$-glucosamidase are absent.

Susceptible to chloramphenicol, ciprofloxacin, imipenem, kanamycin, nalidixic acid, norfloxacin, oxytetracycline, 
rifampicin, streptomycin and tetracycline. Resistant to ampicillin, lincomycin, meticillin, novobiocin, penicillin G, sulfonamide and vancomycin.

The type strain is HKI $454^{\mathrm{T}} \quad\left(=\mathrm{DSM} \quad 19002^{\mathrm{T}}=\mathrm{CIP}\right.$ $109453^{\mathrm{T}}$ ). Isolated from the fungus Rhizopus microsporus van Tieghem var. chinensis.

\section{Description of Burkholderia endofungorum sp. nov.}

Burkholderia endofungorum (en.do.fun.go'rum. N.L. pref. endo- from Gr. endon within; L. gen. pl. n. fungorum of fungi; N.L. gen. n. endofungorum referring to the endosymbiotic nature of this organism with fungi).

Irregularly cultured, Gram-negative, motile, short or coccoid rods that occur singly, in pairs or irregular clusters. Cell size varies from 1.2 to $2.0 \mu \mathrm{m}$ in length and from 0.6 to $1.2 \mu \mathrm{m}$ in width. Cells are positive for oxidase and catalase. Single colonies are tiny, circular, flat, glistening and of cream colour (about $1 \mathrm{~mm}$ in diameter). Growth is poor on agar plates and typically occurs as a very thin lawn. Production of diffusible pigments is not observed. $\mathrm{NaCl}$ is tolerated well up to a concentration of $2 \%(\mathrm{w} / \mathrm{v})$. Growth is negative or weak at a concentration of $3 \%(\mathrm{w} / \mathrm{v}) \mathrm{NaCl}$ and is inhibited completely at $5 \%(\mathrm{w} / \mathrm{v}) \mathrm{NaCl}$. The type strain is able to grow at temperatures between 16 and $45{ }^{\circ} \mathrm{C}$ and at a $\mathrm{pH}$ range of 5.0-7.4. Optimum $\mathrm{pH}$ is 6.0-6.5. Cells are not viable at $\mathrm{pH}$ values below 4.5 or above 7.5. In cultures without $\mathrm{pH}$ control, growth stops at $\mathrm{pH} 7.5$. Glucose is not metabolized, but glycerol is utilized. Able to grow under aerobic and microaerophilic conditions, but not in an anaerobic atmosphere containing $\mathrm{CO}_{2}$.

Phylogenetic distinctiveness is supported by the fatty acid profile, which is characterized by major amounts of hexadecanoic acid (C16:0), cyclo-heptadecanoic acid (C17:0 cyclo), $\omega$-7-cis-octadecenoic acid $(\mathrm{C} 18: 1 \omega 7 c)$ and cyclo- $\omega$-8-nanodecanoic acid $(\mathrm{C} 19: 0 \omega 8 c)$. Positive reactions are obtained for esterase (C4), esterase lipase (C8), leucine arylamidase and naphthol-AS-BI-phosphohydrolase. Alkaline phosphatase, cystine arylamidase, acid phosphatase and $\mathrm{N}$-acetyl- $\beta$-glucosamidase are absent.

Susceptible to chloramphenicol, ciprofloxacin, imipenem, kanamycin, nalidixic acid, norfloxacin, oxytetracycline, rifampicin, streptomycin and tetracycline. Resistant to ampicillin, lincomycin, meticillin, novobiocin, penicillin G, sulfonamide and vancomycin.

The type strain is HKI $456^{\mathrm{T}}\left(=\mathrm{DSM} 19003^{\mathrm{T}}=\mathrm{CIP} 109454^{\mathrm{T}}\right)$. Isolated from the fungus Rhizopus microsporus Tieghem.

\section{Acknowledgements}

We thank the Leibniz association and the DFG for financial support. Excellent technical assistance by M. Cyrulies, R. Kaiser, K. Perlet, C. Schult, G.-M. Schwinger and C. Weigel is gratefully acknowledged. DNA-DNA hybridization experiments were performed by the DSMZ, Braunschweig, Germany.

\section{References}

Bianciotto, V., Lumini, E., Bonfante, P. \& Vandamme, P. (2003). 'Candidatus Glomeribacter gigasporarum' gen. nov., sp. nov., an endosymbiont of arbuscular mycorrhizal fungi. Int J Syst Evol Microbiol 53, 121-124.

Boer, W., Folman, L. B., Summerbell, R. C. \& Boddy, L. (2005). Living in a fungal world: impact of soil bacterial niche development. FEMS Microbiol Rev 29, 795-811.

Bonfante, P. (2003). Plants, mycorrhizal fungi and endobacteria: a dialog among cells and genomes. Biol Bull 204, 215-220.

Bramer, C. O., Vandamme, P., da Silva, L. F., Gomez, J. G. C. \& Steinbuchel, A. (2001). Burkholderia sacchari sp. nov., a polyhydroxyalkanoate-accumulating bacterium isolated from soil of a sugar-cane plantation in Brazil. Int J Syst Evol Microbiol 51, 1709-1713.

Brett, P. J., DeSchazer, D. \& Woods, D. E. (1998). Burkholderia thailandensis sp. nov., a Burkholderia pseudomallei-like species. Int J Syst Bacteriol 48, 317-320.

Burkholder, W. H. (1942). Three bacterial plant pathogens. Phytomonas caryophylli sp. n., Phytomonas alliicola sp. n. and Phytomonas manihotis (Artaud-Berthet and Bondar) Viégas. Phytopathology 32, 141-149.

Caballero-Mellado, J., Martínez-Aguilar, L., Paredes-Valdez, G. \& Estrada-de los Santos, P. (2004). Burkholderia unamae sp. nov., an $\mathrm{N}_{2}$-fixing rhizospheric and endophytic species. Int $J$ Syst Evol Microbiol 54, 1165-1172.

Coenye, T. \& Vandamme, P. (2003). Diversity and significance of Burkholderia species occupying diverse ecological niches. Environ Microbiol 5, 719-729.

Coenye, T., LiPuma, J. J., Henry, D., Hoste, B., Vandemeulebroecke, K., Gillis, M., Speert, D. P. \& Vandamme, P. (2001a). Burkholderia cepacia genomovar VI, a new member of the Burkholderia cepacia complex isolated from cystic fibrosis patients. Int J Syst Evol Microbiol 51, 271-279.

Coenye, T., Laevens, S., Willems, A., Ohlen, M., Hannant, W., Govan, J. R. W., Gillis, M., Falsen, E. \& Vandamme, P. (2001b). Burkholderia fungorum sp. nov. and Burkholderia caledonica sp. nov., two new species isolated from the environment, animals and human clinical samples. Int J Syst Evol Microbiol 51, 1099-1107.

Coenye, T., Mahenthiralingam, E., Henry, D., LiPuma, J. J., Laevens, S., Gillis, M., Speert, D. P. \& Vandamme, P. (2001c). Burkholderia ambifaria sp. nov., a novel member of the Burkholderia cepacia complex including biocontrol and cystic fibrosis-related isolates. Int $J$ Syst Evol Microbiol 51, 1481-1490.

Coenye, T., Vandamme, P., Govan, J. R. W. \& LiPuma, J. J. (2001d). Taxonomy and identification of the Burkholderia cepacia complex. J Clin Microbiol 39, 3427-3436.

Cowan, S. T. \& Steel, K. J. (1965). Manual for the Identification of Medical Bacteria. Cambridge: Cambridge University Press.

Goris, J., De Vos, P., Caballero-Mellado, J., Park, J., Falsen, E., Quensen, J. F., III, Tiedje, J. M. \& Vandamme, P. (2004). Classification of the biphenyl- and polychlorinated biphenyl-degrading strain LB400T and relatives as Burkholderia xenovorans sp. nov. Int J Syst Evol Microbiol 54, 1677-1681.

Huelsenbeck, J. P. \& Ronquist, F. (2001). MRBAYES: Bayesian inference of phylogenetic trees. Bioinformatics 17, 754-755.

Huelsenbeck, J. P., Ronquist, F., Nielsen, R. \& Bollback, J. P. (2001). Bayesian interface of phylogeny and its impact on evolutionary biology. Science 294, 2310-2314.

Lim, Y. W., Baik, K. S., Han, S. K., Kim, S. B. \& Bae, K. S. (2003). Burkholderia sordidicola sp. nov., isolated from the white-rot fungus Phanerochaete sordida. Int J Syst Evol Microbiol 53, 1631-1636. 
Lumini, E., Ghignone, S., Bianciotto, V. \& Bonfante, P. (2006). Endobacteria or bacteria endosymbionts? To be or not to be. New Phytol 170, 205-208.

Page, R. D. M. (1996). TreeView: an application to display phylogenetic trees on personal computers. Comp Appl Biosci 12, 357-358.

Partida-Martinez, L. P. \& Hertweck, C. (2005). Pathogenic fungus harbours endosymbiotic bacteria for toxin production. Nature 437, 884-888.

Partida-Martinez, L. P. \& Hertweck, C. (2007). A gene cluster encoding rhizoxin biosynthesis in 'Burkholderia rhizoxina', the bacterial endosymbiont of the fungus Rhizopus microsporus. ChemBioChem 8, 41-45.

Partida-Martinez, L. P., Flores de Looss, C., Ishida, K., Ishida, M., Roth, M., Buder, K. \& Hertweck, C. (2007a). Rhizonin, the first mycotoxin isolated from the zygomycota, is not a fungal metabolite but is produced by bacterial endosymbionts. Appl Environ Microbiol 73, 793-797.

Partida-Martinez, L. P., Monajembashi, S., Greulich, K. O. \& Hertweck, C. (2007b). Endosymbiont-dependent host reproduction maintains bacterial-fungal mutualism. Curr Biol 17, 773-777.

Reis, V. M., Estrada-de los Santos, P., Tenorio-Salgado, S., Vogel, J., Stoffels, M., Guyon, S., Mavingui, P., Baldani, V. L. D., Schmid, M. \& other authors (2004). Burkholderia tropica sp. nov., a novel nitrogenfixing, plant-associated bacterium. Int J Syst Evol Microbiol 54, 2155-2162.

Scherlach, K., Partida-Martinez, L. P., Dahse, H. M. \& Hertweck, C. (2006). Antimitotic rhizoxin derivatives from a cultured bacterial endosymbiont of the rice pathogenic fungus Rhizopus microsporus. J Am Chem Soc 128, 11529-11536.

Schmitt, I. \& Lumbsch, T. (2004). Molecular phylogeny of the Pertusariaceae supports secondary chemistry as an important systematic character set in lichen-forming ascomycetes. Mol Phylogenet Evol 33, 43-55.

Sessitsch, A., Coenye, T., Sturz, A. V., Vandamme, P., Barka, E. A., Salles, J. F., Van Elsas, J. D., Faure, D., Reiter, B. \& other authors (2005). Burkholderia phytofirmans sp. nov., a novel plant-associated bacterium with plant-beneficial properties. Int J Syst Evol Microbiol 55, 1187-1192.
Smibert, R. M. \& Krieg, N. R. (1994). Phenotypic characterization. In Methods for General and Molecular Bacteriology, pp. 607-654. Edited by P. Gerhardt, R. G. E. Murray, W. A. Wood, N. R. Krieg. Washington, DC: American Society for Microbiology.

Swofford, D. L. (2003). PAUP ${ }^{*}$ : phylogenetic analysis using parsimony (*and other methods). Sunderland, MA: Sinauer Associates.

Thompson, J. D., Gibson, T. J., Plewniak, F., Jeanmougin, F. \& Higgins, D. G. (1997). The CLUSTAL_X windows interface: flexible strategies for multiple alignment aided by quality analysis tools. Nucleic Acids Res 25, 4876-4882.

Van Oevelen, S., De Wachter, R., Vandamme, P., Robbrecht, E. \& Prinsen, E. (2002). Identification of the bacterial endosymbionts in leaf galls of Psychotria (Rubiaceae, angiosperms) and proposal of 'Candidatus Burkholderia kirkii' sp. nov. Int J Syst Evol Microbiol 52, 2023-2027.

Van Oevelen, S., De Wachter, R., Vandamme, P., Robbrecht, E. \& Prinsen, E. (2004). 'Candidatus Burkholderia calva' and 'Candidatus Burkholderia nigropunctata' as leaf gall endosymbionts of African Psychotria. Int J Syst Evol Microbiol 54, 2237-2239.

Viallard, V., Poirier, I., Cournoyer, B., Haurat, J., Wiebkin, S., OphelKeller, K. \& Balandreau, J. (1998). Burkholderia graminis sp. nov., a rhizospheric Burkholderia species, and reassessment of [Pseudomonas] phenazinium, [Pseudomonas] pyrrocinia and [Pseudomonas] glathei as Burkholderia. Int J Syst Bacteriol 48, 549-563.

Yabuuchi, E., Kosako, Y., Oyaizu, H., Yano, I., Hotta, H., Hashimoto, Y., Ezaki, T. \& Arakawa, M. (1992). Proposal of Burkholderia gen. nov. and transfer of seven species of the genus Pseudomonas homology group II to the new genus, with the type species Burkholderia cepacia (Palleroni and Holmes 1981) comb. nov. Microbiol Immunol 36, 1251-1275.

Yang, H. C., Im, W. T., Kim, K. K., An, D. S. \& Lee, S. T. (2006). Burkholderia terrae sp. nov., isolated from a forest soil. Int J Syst Evol Microbiol 56, 453-457.

Zhang, H., Hanada, S., Shigematsu, T., Shibuya, K., Kamagata, Y., Kanagawa, T. \& Kurane, R. (2000). Burkholderia kururiensis sp. nov., a trichloroethylene (TCE)-degrading bacterium isolated from an aquifer polluted with TCE. Int J Syst Evol Microbiol 50, 743-749. 